\title{
THE EFFECT OF HEALTH PROMOTION ABOUT DISASTER MANAGEMENT TOWARDS THE LEVEL OF KNOWLEDGE OF YOUTH RED CROSS MEMBERS
}

\author{
Loren Juksen $^{1}$, Ida Rahmawati ${ }^{*}$, Qrestha Utami $^{2}$ \\ ${ }^{1}$ Lecturer Nursing Study Program STIKES Tri Mandiri Sakti Bengkulu \\ ${ }^{2}$ Student Nursing Study Program STIKES Tri Mandiri Sakti Bengkulu \\ *Correspondence: \\ Ida Rahmawati \\ Email: idarahmawati1608@gmail.com \\ Address: STIKES Tri Mandiri Sakti Bengkulu, Jalan Hibrida Raya no.3, Bengkulu City
}

\begin{abstract}
Background: The potential for natural disasters in Bengkulu is very worrying. Mukomuko is one of the districts in Bengkulu Province which has a geographical location prone to earthquakes and Tsunami. Preparedness and disaster mitigation in school students is still low. Members of the youth red cross in senior high schools have never been exposed to disaster management.

Objectives: The aim of this study was to determine health promotion to increasing knowledge about disaster management on students of youth red cross members.

Methods: This study used pre and posttest without control group design. Population in this study were all students of youth red cross members at SMA Negeri 1 Mukomuko Bengkulu with the amount of 30 people. Sampling technique in this study used total sampling obtained samples were 30 people. Collecting data in this study used primary data obtained from SMA Negeri 1 Mukomuko and secondary data with filled out questionnaire.

Results: The results of this study showed: (1) from 30 people there were 13 people $(43,3 \%)$ before treatment were good knowledge, 16 people $(53,3 \%)$ before treatment were moderate knowledge, and 1 people $(3,3 \%)$ before treatment were low knowledge; (2) from 30 people there were 18 people $(60 \%)$ after treatment were good knowledge and 12 people $(40 \%)$ after treatment were moderate knowledge; (3) results of Paired Sample t-test obtained value of $\mathrm{t}=3,023$ with $\mathrm{p}$-value $=0,005<0,05$ significant means there was significant differences between knowledge about Disaster Management on Students before treatment and knowledge about Disaster Management on Students after treatment.

Conclusion: The importance of direct information from health workers regarding disaster management has a continuing impact to be applied by youth red cross students when a disaster occurs.
\end{abstract}

Key words: Health Promotion, Knowledge, Disaster Management.

\section{INTRODUCTION}

All of the human dwelling place territories have disaster risks. Causative factor of disaster likes natural conditions and non - cultural conditions nor due to humans (BNPB, 2017). Indonesia is a disaster region. At least there are 12 disaster threats that are grouped in disaster geology (earthquake, tsunami, volcano, land movement and landslide), hydrometeorology disasters (flood, flash flood, drought, extreme weather, forest fires and land fires) and anthropogenic disasters (Epidemic of disease and field technology or industrial accidents) (Wijaya et al, 2015). Badan Nasional Penangulangan Bencana (BNPB) record the whole years of 2018 have occurred 
1.999 disasters in Indonesia. Consciousness and alertness of society towards disaster is still low (BNPB, 2017)

Potency of disasters in Bengkulu Province is very worrying. From data of BNPB of Bengkulu Province, there are dozens sub-districts or village in 9 regencies and 1 city are natural disasterprone, like landslide, flash flood, tsunami, earthquake and flood. BPBD of Mukomuko Regency, Bengkulu Province states that six of $15 \mathrm{Sub}$ - district in along the coast is tsunami disaster-prone. When the largest earthquake occurred that six of sub-district was tsunami disaster-prone. The six of disaster prone were Air Rami, Ipuh, Pondok Suguh, Teramang Jaya, Air Dikit, Mukomuko and Lubuk Pinang (CAH, 2015)

The Geographical location of Mukomuko regency is along the West Coast of Sumatera and convergence boundary tectonic plate of Eurasian and Indo-Australian. The plates are active plate in which Indo - Australian Plate moving to the north, whereas Eurasian plate moving to south and collision (Wijaya, Andarini, \& Setyoadi, 2015). Thus, forming a subduction zone in along convergence of both plates. Indo-Australian Plate infiltrate down Eurasian plate which creates the subduction zone. This Subduction Zone is a generator of the tectonic earthquakes in Mukomuko (Akmam, 2011).

Indonesian Disaster Risk Index (IRBI) in 2013 noted that there were $80 \%$ Indonesian region has high risk towards disaster, including 205 million people exposed to disaster and 107 million people were children with school age (BNPB, 2013). The breadth of exposure and consideration of disaster risk then required integrated efforts, synchronous and synergistic between government agencies, school, societies and business world to prevent of risk by doing preparedness and to ensure early warning system.

Impact of disaster can be felt more severe if occurred on teaching-learning process in school, because building ruins and surrounding objects able to befall students, teacher and staffs (BNPB, 2013). By education hoped so that disaster risk decreasing efforts able to reach the broader target and able to introduced early to students. Like by integrating disaster risk decreasing education to school curriculum and extracurricular activity and etc. then effort to ensure that school environment and education facilities secure of disaster and not place which able to endanger the life of students, teacher, and staffs (Suharwoto, 2015).

Based on the result of the research survey, SMAN 1 Mukomuko is either school which is located closer to the coast and closest with earthquake and tsunami. Vice of headmaster conveys that students of SMAN1 Mukomuko are not ever yet conducted disaster education.

\section{METHODS}

Study Design

The design of this research used preexperimental design with pre and posttest without control group design.

\section{Setting}

Location of this research conducted in SMAN 1 Mukomuko, Bengkulu.

\section{Research Subject}

The Population of this research is all of the students young red cross in SMAN 1 Mukomuko as many as 30 respondents. The Sample in this research is all of the students young red cross in SMAN 1 Mukomuko as many as 30 respondents. Sampling technic used total sampling that is the population becomes sample.

\section{Instruments}

The Instrument in this research used questionnaire. To measure of knowledge used questionnaire by 15 close-ended questions which were created by the researcher. The question of the questionnaire has content the knowledge 
of the student related disaster management. The researcher before conduced validity test used product moment correlation, the question is valid if computed $\mathrm{R}>$ table $\mathrm{R}$ with the level of significant $5 \%$ (Sugiyono, 2009). From 20 questions which were tested, there were some questions which were not valid that were no 5, 8, 12, 1, 16. Having conducted retest of validity were obtained the valid question were questions number $1,2,3,4$, $6,7,9,10,11,13,15,17,18,19$ and 20. After that the analysis was continued to the reliability test. The reliability test was measured to compare the value of Alpha $R$ and table $\mathrm{R}$, if Alpha $\mathrm{R}>$ table $\mathrm{R}$ then that questionnaire is reliable. From the result of the reliability on questionnaire was obtained alpha $\mathrm{r}=0.869$ and table $\mathrm{r}=$ 0.2960 . the conclusion is the questionnaire is reliable that was created by researcher. The questions of the questionnaire contained the knowledge of the students related disaster management. The Researcher before conducted the validity test using correlation product moment where the questions is valid if the value of $r$ computed $>r$ table with the significant level is 5\% (Sugiyono,2009). From 20 questions that were tested, there were some questions were not valid, that were questions number $5,8,12,14,16$ and the questions were valid, that were questions number $1,2,3,4,6,7,9,10,11,13,15$, 17, 18, 19, and 20. And after that the analysis was continued to reliability test. The reliability test was measured to compare $r$ Alpha and $r$ table, if $r$ Alpha $>r$ table then the questionnaire was valid. From the result of reliability test on the questionnaire was obtained that $\mathrm{r}$ Alpha $=$ 0.869 and $\mathrm{r}$ table 0.2960 . The conclusion is that questionnaire is reliable.

The result of the measurement of the knowledge questionnaire divided into 3 , that are low level if the respondents be able to answer of the questions as many as 1-5 questions, moderate level if respondents be able to answer of the questions as many as 6-10 questions and good level if be able answer as many as 11-15 questions.

\section{Data Analysis}

Data analysis conducted by univariate and bivariate analysis. Normality data used Saphiro-Wilk because of sample $<50$ persons. Statistic test used paired sample T-test.

\section{Ethical Consideration}

This research obtained letter of permission from National Unity and Politics of Mukomuko, Bengkulu Province with No 070/36/F.2/IV/2019.

\section{RESULTS}

Characteristics of Respondents by Age, Gender, and Level of Knowledge

Table 1. Distribution of Frequency of Respondents by Age, Gender and Level of Knowledge in SMAN 1 Mukomuko, Bengkulu $(\mathrm{n}=30)$.

\begin{tabular}{|c|c|c|}
\hline $\begin{array}{l}\text { Characteristic } \\
\text { of Respondent }\end{array}$ & Frequency & $\begin{array}{c}\text { Percentages } \\
(\%)\end{array}$ \\
\hline \multicolumn{3}{|l|}{ Age } \\
\hline $15-16$ & 15 & $50 \%$ \\
\hline $17-18$ & 15 & $50 \%$ \\
\hline \multicolumn{3}{|l|}{ Gender } \\
\hline Man & 7 & $23.3 \%$ \\
\hline Woman & 23 & $76.6 \%$ \\
\hline \multicolumn{3}{|l|}{$\begin{array}{l}\text { Level of } \\
\text { knowledge } \\
\text { before } \\
\text { treatment }\end{array}$} \\
\hline Good & 13 & $43.3 \%$ \\
\hline Moderate & 16 & $53.3 \%$ \\
\hline Low & 1 & $3.3 \%$ \\
\hline \multicolumn{3}{|l|}{$\begin{array}{l}\text { Level of } \\
\text { knowledge } \\
\text { after } \\
\text { treatment }\end{array}$} \\
\hline Good & 18 & $60.0 \%$ \\
\hline Moderate & 12 & $40.0 \%$ \\
\hline
\end{tabular}


to 18 years old. Gender known most of the respondents that are registered as youth red cross members in SMAN 1 Mukomuko were female as many as 23 respondents and male as many as 7 respondents. The results showed that the level of knowledge before treatment was that most had a moderate level of knowledge of 16 respondents (53.3\%), while after treatment it was found that most had a good level of knowledge of 18 respondents $(60.0 \%)$.

Examination of The Effect of Health Promotion about Disaster Management towards The Level of Knowledge of Youth Red Cross Members in SMAN 1 Mukomuko, Bengkulu

Table 2. Crosstabulation of Level of Knowledge Before and After Treatment about Disaster Management in SMAN 1 Mukomuko $(\mathrm{n}=30)$.

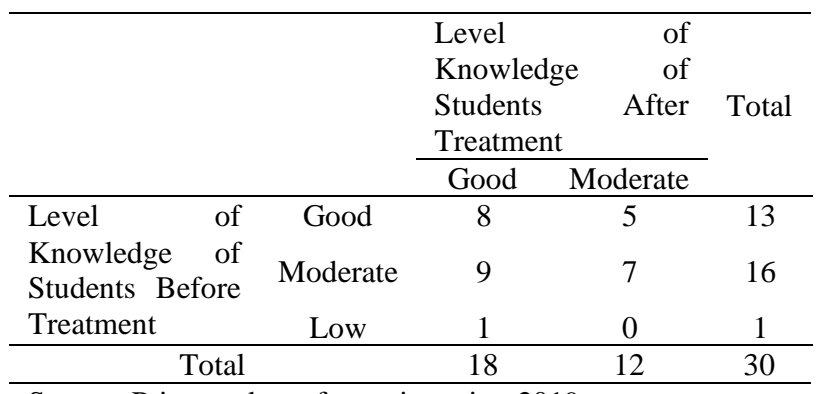

Source: Primary data of questionnaire, 2019

Based on table 2 obtained that data from 13 respondents who had good level before treatment, there were 8 respondents were good level and 5 respondents were moderate level after treatment. From 16 respondents who had moderate level before treatment, there were 9 respondents were good level and 7 persons were moderate level after treatment. From 1 person who had low level before treatment, there was no person who had low level after treatment. After treatment, there were 18 persons who had good level and 12 persons who had moderate level.

Normality data test in this research used Shapiro-Wilk. This thing caused the number of respondents less than 50 persons. on this normality test was obtained $p$-value $=0.200>0.05$ for knowledge data of students about disaster management before treatment and $p$-value $=0.053>0.05$ for knowledge data of students about disaster management after treatment, due to knowledge data group of students about disaster management, before and after were normally distributed, so that qualify to conduct statistic test that is paired sample T-test. Then, statistic test that will conduct on this research is paired sample T-test.

The value of pre-test was obtained that knowledge rates of students about disaster management before treatment were 9.8 and deviation standard was 2.156 and knowledge rates about of students about disaster management after treatment were 10.77 and deviation standard was 1.96. The number of students who were used as research sample as many as 30 persons. And the last is standard of error mean to pre-test as many as 0.394 and to post-test as many as 0.358 .

The result of correlation test shows that between knowledge of the students before and after treatment about disaster management were obtained the value of correlation coefficient as 0.642 and $p$ value $=0.000$, due to the value of the correlation coefficient in interval 0.600.80 , then its correlation is the close category or there is relationship between pre-test and post-test.

The result of paired sample T-test were obtained the value of $\mathrm{T}=-3.023$ then $\mathrm{T}=|-3,023|=3,023$ and $p$-value $=$ $0.000<0.05$ means there is significant relationship between before and after treatment.

\section{DISCUSSION}

Indonesia is disaster-prone country. That reality cannot be denied remembering the condition of geographic is located on three plate meeting point Eurasia, IndoAustralia, and Pacific and on the ring of 
fire (BNPB, 2013). The threat of disaster in Bengkulu Province according to Disaster Risk Index in years 2013 that are earthquake, tsunami, wildfire settlement, drought, landslide, volcano, and abrasion (BNPB, 2013). Individual and group need to conduct disaster preparedness through increasing of knowledge factor, attitude, policy, early warning system and resources mobilization (Husna, 2012).

The essence of disaster management is either of human life protection act and environment. Disaster management is focused on prevention activity, mitigation, preparedness and vigilance (Sutanto, 2012). An embodiment of mitigation efforts from school are including disaster curriculum which is the part of nonstructural disaster mitigation. To create the disaster education need to comprehensive efforts which are centered on the student (Amri, 2017). Emergency situation while disaster must be concerning importantly for every person (Nurkartika, Murakami, \& Chagan-yasutan, 2018). Young red cross is either of part of student trained who able to understand the situation of disaster. Although, integration of health education for young red cross must be conducted. The research about health education in reducing of disaster conducted by Pascapurnama et al., (2018) shows that education able to increasing self -vigilance and disaster preparedness.

Education is either of effort preparedness to society to be able to improvise self - vigilance system towards disaster. The research which was conducted by Dien (2015) stated that there is an effect of health education towards preparedness facing earthquake on students in the school. The institute of education such as senior high school is either of targets to conducted disaster management education. Behavior alteration that is resulted from education must be based on knowledge and awareness during learning process is exerted (Notoadmojo, 2012). The good knowledge about disaster management is very important to known by young red cross members especially at SMAN 1 Mukomuko. This thing due to the frequency of disaster in Mukomuko regency such as earthquake and tsunami potential with the position of the building of SMAN 1 is very close to the coast.

Based on information of vice headmaster of SMAN 1 Mukomuko that not ever yet the health education activity about disaster management so that this thing to encourage youth red cross focus on education activity that conveyed by the educator. Moreover, the materials which were used in this research were laptop, LCD, leaflet, and sounds system. When the education was taking place, the educator used teaching method. The researcher presented the health education through power point application and using text and images so that the students be able to focus, interested, and increasing the knowledge level of the student related disaster management. This thing appropriates with the research was created by Saanun \& Kumaat (2017) that showed there is effect health education and teaching method and discussion method towards preparedness in face of disaster. This thing was proved in research with the result that the effectiveness of modification teaching method using media has deep effect in increasing of preparedness of the student in face of disaster (Widjanarko \& Minnafiah, 2018).

Factors that create knowledge about disaster management are not conveyed to the respondents, especially to respondent from good knowledge to fair (1 person) and respondents who were not improved from fair knowledge (11 persons) that were while health education is taking place and the respondents were not focused to the presentation. Then, the atmosphere of health education room was not the same in the classroom because the school only provided for the education at the chemical laboratory where chairs were lined up 
close together so that, the students was not focused to the presentation at the time. These things the same with Notoatmodjo theory (2012) that knowledge is the result of know and occurs after someone conducting sensing towards one object.

Nursing implications in this research towards the school of nursing able to become as additional information resources about the role and function of the nurses at the school that have stead in nursing students learning. Nurses need to know and understand the role and their function and how to apply it.

\section{CONCLUSION}

The results of this research show that health education about disaster management is very important and beneficial for youth red cross as the volunteers of health at the school. And there were differences between knowledge before and after health education.

\section{SUGGESTIONS}

The result of the research able to become as main materials learning of disaster and evidence-based practice to school in coast region which is risked towards tsunami and earth quake. The result of the research able to become basis data in efforts to be curriculum and topic for student training at the school and efforts overcomes emergency situation or disaster in Indonesia. The socialization regarding disaster management is still not more conducted by the health worker, so that information which is obtained by the school is still not optimal. The members of the Youth Red Cross as either health worker able to conduct training by collaboration with cross- sectoral institution such as BNPB, PMI and other institution so the school able to understand the important of disaster management.

\section{ACKNOWLEDGMENT}

The authors are pleased to thanks the mentors, hospital, and colleagues who have spent much time and ideas for the completion of this research.

\section{DECLARATION OF CONFLICTING INTEREST}

There is no conflict of interest in this research.

\section{FUNDING}

This research was funded by author.

\section{AUTHOR CONTRIBUTION}

Each author contributes to the completion of the article.

\section{ORCID}

Loren Juksen

None

Ida Rahmawati

http://orcid.org/0000-0001-7401-6214

Qrestha Utami

None

\section{REFERENCES}

Akmam. (2011). Subduksi lempeng indoaustralia pada lempeng eurasia di pantai barat sumatera barat. Jurnal Sainstek, III(1), 52-59.

Amri, A. (2017). Pendidikan Tangguh Bencana "Mewujudkan Satuan Pendidikan Aman Bencana di Indonsia." Jakarta.

BNPB. (2013). Indeks Risiko Bencana Indonesia. Jakarta: Direktorat Pengurangan risiko Bencana Deputi Bidang Pencegahan dan Kesiapsiagaan. Retrieved from http://weekly.cnbnews.com/news/artic le.html?no=124000

BNPB. (2016). Risiko bencana indonesia. Jakarta.

BNPB. (2017). Buku Pedoman Latihan Kesiap Siagaan Bencana: Membangun Kesadaran, Kewaspadaan, dan Kesiap Siagaan dalam Menghadapi Bencana. Retrieved from 
https://siaga.bnpb.go.id/hkb/pocontent/uploads/documents/buku_pan duan_latihan_kesiapsiagaan_bencana _revisi_april_2017.pdf

CAH. (2015). Enam Kecamatan di Mukomuko Rawan Bencana Tsunami. Retrieved December 15, 2018, from https://www.beritasatu.com/nasional/ 301087/enam-kecamatan-dimukomuko-rawan-bencana-tsunami

Dien, R. J. (2015). Pengaruh Penyuluhan Kesehatan Terhadap Kesiapsiagaan Menghadapi Bencana Gempa Bumi Pada Siswa Smp Kristen Kakaskasen Kota Tomohon. Jurnal Keperawatan, $3(2)$.

Husna, C. (2012). Influencing Factors on Disaster Preparedness in RSUDZA Banda Aceh Cut Husna. IIdea Nursing Journal, III(2), 10-19.

Notoadmojo, S. (2012). Promosi kesehatan dan perilaku kesehatan. Jakarta: Rineka Cipta.

Nurkartika, D., Murakami, A., \& Chaganyasutan, H. (2018). International Journal of Disaster Risk Reduction Integrated health education in disaster risk reduction: Lesson learned from disease outbreak following natural disasters in Indonesia. International Journal of Disaster Risk Reduction, 29(July 2017), 94-102.

Pascapurnama, D. N., Murakami, A., Chagan-Yasutan, H., Hattori, T., Sasaki, H., \& Egawa, S. (2018). Integrated health education in disaster risk reduction: Lesson learned from disease outbreak following natural disasters in Indonesia. International Journal of Disaster Risk Reduction, 29(July), 94-102.

Saanun, F., \& Kumaat, L. T. (2017). Pengaruh penyuluhan kesehatan terhadap kesiapsiagaan dalam menghadapi bencana tanah longsor pada siswa kelas XI SMK Negeri 6 Manado. E-Journal Keperawatan, 5(1), 1-7.
Penelitian Kuantitatif. (Endang Mulyaningsih, Ed.) (10th ed.). Bandung: CV Alfabeta.

Suharwoto, G. (2015). Modul 2 pilar 2manajemen bencana di sekolahSPAB. Jakarta: Kementerian Pendidikan dan Kebudayaan.

Sutanto. (2012). Peran K3 Dalam Manajemen Bencana. Media Komunikasi Rekayasa Dan Teknologi Tepat Guna, 8(2), 37-40.

Widjanarko, M., \& Minnafiah, U. (2018). Pengaruh Pendidikan Bencana Pada Perilaku Kesiapsiagaan Siswa. Jurnal Ecopsy, 5(1), 1.

Wijaya, S., Andarini, S., \& Setyoadi. (2015). Survivor Pertolongan Kesehatan Saat Respon Tanggap Darurat Pada Korban Bencana Tsunami Tahun 2004 Di Lhoknga Dan Lhoong. Jurnal Kesehatan Wiraraja Medika, 108-117.

Cite This Article As: Juksen, L., Rahmawati, I., \& Utami, Q. The Effect of Health Promotion about Disaster Management towards The Level of Knowledge of Youth Red Cross Members. Nurse and Health: Jurnal Keperawatan 2019; 8(2): 62-68. 